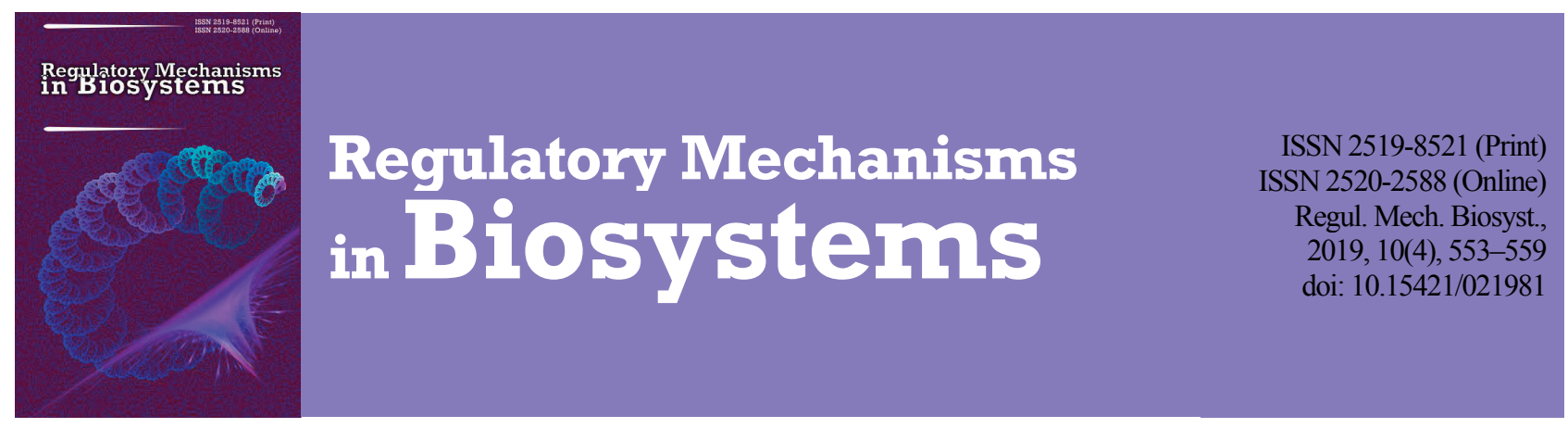

\title{
Environmental factors affecting flavonoid accumulation in plants Poligonum weyrichii growing in Murmansk region
}

\author{
A. V. Korovkina*, V. K. Zhirov**** \\ *Kola Science Centre of the Russian Academy of Sciences, Apatity, Russia \\ **Polar Alpine Botanical Garden and Institute of the Russian Academy of Sciences, Apatity, Russia
}

Article info

Received 26.09.2019

Received in revised form 17.10.2019

Accepted 18.10.2019

Kola Science Centre

of the Russian Academy

of Sciences, Fersman st., 41 a

Apatity, Murmansk region,

184209, Russia.

Tel.: +7-815-557-96-34.

E-mail:dokktorr@list.ru

Polar Alpine Botanical

Garden and Institute

of the Russian Academy

of Sciences, Fersman st.

18a, Apatity, Murmansk

region, 184209, Russia.

Tel.: +7-815-556-33-50

E-mail:

v_zhirov_1952@mail.ru

\section{Introduction}

Murmansk region is an area with harsh living conditions for the population, which are caused by the simultaneous action of extreme factors of natural and anthropogenic origin. Since the main part of the region is located beyond the Arctic Circle, it is characterized by a pronounced lack of heat, a short vegetation time, high humidity and extreme lighting conditions, reverse flipping between polar day and polar night (Marshall et al., 2016). The location of Murmansk region between two seas and the mainland causes the frequent occurrence of atmospheric vortices with a large amount of precipitation (Zhirov et al., 2007). Considerable cloudiness is the reason for the $45-50 \%$ decrease in the total solar radiation exposure, and the location at high latitudes $\left(63-66^{\circ}\right)$ in the auroral oval zone - the instability of the geomagnetic field and increased activity of cosmic radiation, which, according to popular opinion, is one of the main causes of chronic "northern" stress (Hasnulin, 2007). At the same time, an important role in its formation is also played by the disturbance of the natural environment by objects of the mining and ore-dressing industries, wastes of which pollute the soil, the air and water basins (Law et al., 2017). The ecological situation is worsening in the Kola Peninsula, which affects the health of the local population, with this situation becoming more and more pronounced in the last few years. As the life of a person in extreme ecological and geographical conditions results in more intensive use and fast exhaustion of his adaptive resources, the course of chronic diseases is complicated, the aging processes accelerate, and life expectancy is reduced.
Cardiovascular diseases are the dominating in the structure of the overall morbidity, mortality and disability of the adult population of Murmansk region. At the same time, the incidence of circulatory system diseases is steadily increasing $(2008-244.7$ people per 100 thousand people, 2009-246.8, 2010 - 269.8, 2013-570.2, 2014-617.3, 2015635.5 ), and now the rate of mortality of the population caused by circulatory system diseases is $57 \%$ (Korovkina, 2019).

According to modern hypothesis, the basis of many cardiovascular diseases is the formation of endothelial dysfunction (Salvamani et al., 2014; Kim \& Je, 2017). Damaging factors activate the accumulation of free radicals that cause oxidative damage to membranes and the endothelial function of the blood vessels, which are an essential component of almost all cardiovascular diseases - ischemic heart disease, arterial hypertension, atherosclerosis, chronic heart failure, etc. (Phaniendra et al., 2015; Incalza et al., 2018).

Inhibition of free radical oxidation (FRO) is provided by a complex of extinguishers of free radicals and antioxidants - low molecular weight compounds and enzymes, mainly ingested with food (Panche et al., 2016; Zhang \& Tsao, 2016). However, since FRO takes part in the regulation of mitotic activity, immune reactions, detoxification of exogenous compounds, etc. (Cheynier et al., 2013; del Rio, 2015), at the membrane level, the adaptation mechanisms are associated with the maintenance of the physiological activity of FRO, including not only anti-, but also prooxidants. One of these ensembles is represented by a complex of flavonoid compounds (Carocho \& Ferreira, 2013; Eghbaliferiz \& Iranshahi, 2016). 
Flavonoids are an extensive group of polyphenols, exhibiting both anti- and prooxidant activity, widespread in plants and representing an important component of the mechanism of their nonspecific adaptations to adverse environmental conditions (Panche et al., 2016). It is well known that in plants under the action of extreme factors, the content of flavonoids, as well as other low-molecular biologically active compounds, can significantly increase (Yang et al., 2018). The widespread use of flavonoids in medical practice is justified by the uniformity of the mechanisms of nonspecific membrane level adaptations in plants and animals (Nimse \& Pal, 2015). At present, the flavonoid compounds are considered to be promising endothelial protectors used under different states related to the progression of endothelial dysfunction and oxidative stress. There is a great amount of data on the fact that flavonoids can improve the prognosis of patients with cardiovascular disease and reduce the risk of acute complications (Kim \& Je, 2017).

Since animals are not able to produce flavonoids, and their artificial synthesis is associated with significant costs, plants are the only sources of these adaptogens (Brunetti et al., 2013). At the same time, the extreme complexity of the flavonoid pool, which includes numerous minor components, ensures the maintenance of the physiological balance between the processes of formation and metabolization of reactive oxygen species, but makes its artificial reproduction practically impossible. Thus, one of the promising approaches to solving the problems of prevention and treatment of cardiovascular diseases, the primary mechanisms of which are associated with impaired regulation of FRO, is a detailed study of the dependence of the synthesis of flavonoids in plants on environmental conditions of their habitats. Taking into account the data available on a more intensive synthesis of adaptogenic compounds by plants affected by the extreme factors of various nature, we can presume that the Arctic regions may be one of the most significant source of pharmaceutically valuable medicinal plants (Jaakola \& Hohtola, 2010). In the Murmansk region, this approach is of particular importance due to the apparent increase in cardiovascular diseases of the population, as well as the necessity of import substitution, declared in recent years, including in the field of pharmaceutical production.

Among the plants growing in the Murmansk region, the most promising as a possible source of flavonoids is Weyrich's knotweed (Poligonum weyrichii Fr. Schmidt) introduced to the Kola Peninsula in the 1920s (Fig. 1).

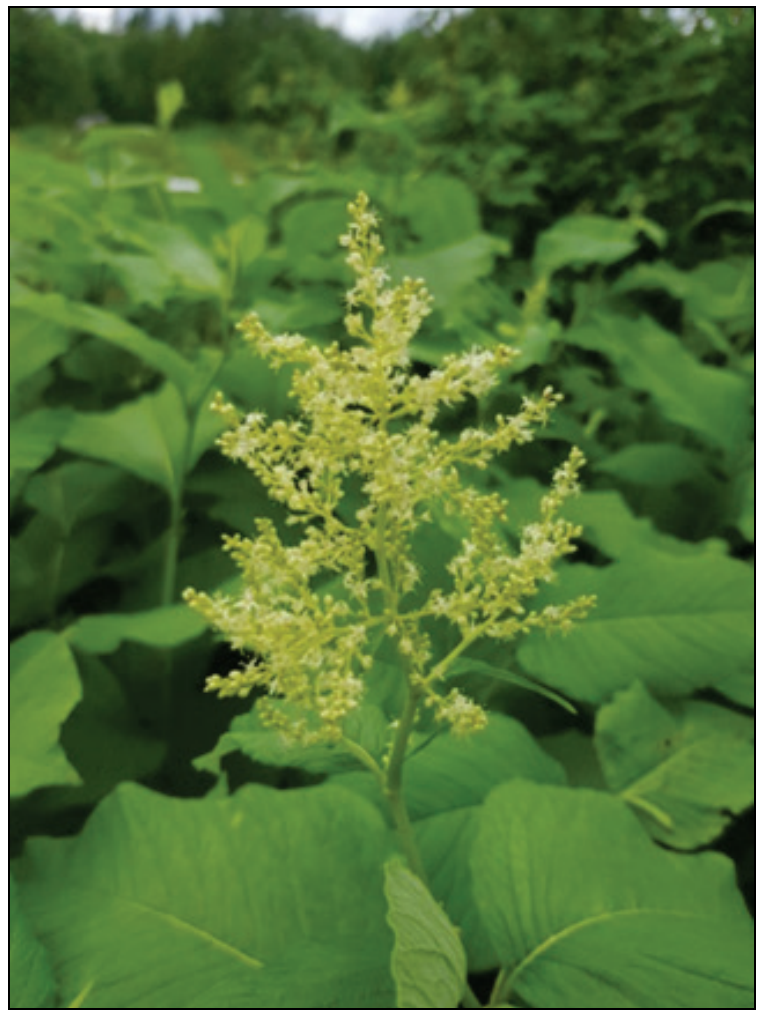

Fig. 1. P. weyrichii plants
The plant $P$. weyrichii contains the following flavonoids: avicularin, hesperidin, quercetin, hyperoside, quercetin-3-rhamnosid, kaempferol, myricetin, rutin, epigallocatechin, epicatechin (Shreteret al., 2002). At present, the following types of pharmacological activity of the flavonoids mentioned are determined, such as: vasoprotective (Suganya et al., 2018), diuretic (Zeng et al., 2019), antiviral (Guo et al., 2019), anticarcinogenic (Siddiq et al., 2018), anti-inflammatory (Maleki et al., 2019), anti-thrombogenic (Vazhappilly et al., 2019), anti-oxidant (Siasos et al., 2013) and others (Sunil \& Xu, 2019; Wang et al., 2019).

Representatives of this species have effectively naturalized in local conditions and are now widely distributed throughout the industrialized part of the region. Plants of $P$. weyrichii are distinguished by high frost resistance and yield, even in adverse conditions of the foothills and proximity to industrial facilities. It is known that with significant biomass (in Murmansk region, these plants reach a height of $3 \mathrm{~m}$ ), their tissues are rich in flavonoids, and can thus be considered as a promising source for flavonoids in Murmansk region. For the organization of appropriate production, the issue of the influence of cultivation conditions, which had not been raised beforehand, as well as, taking into account the landscape diversity of Murmansk region, the height of habitat area on the flavonoid content in these plants, is of fundamental importance.

This work is the pilot study in exploring the possibilities of using the $P$. weyrichii plants as a source of flavonoid compounds for the production of adaptogenic drugs in Murmansk region. At this stage, the study was focused on ecological factors of the accumulation of flavonoids in the tissues of various organs of these plants during the growing season in its two, differing in climatic conditions, districts.

\section{Materials and methods}

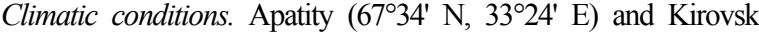
$\left(67^{\circ} 36^{\prime} \mathrm{N}, 33^{\circ} 40^{\prime} \mathrm{E}\right)$ areas are located at a close distance from each other $(24 \mathrm{~km})$. However, they differ in climatic conditions (Zhirov et al., 2007). The experimental site Apatity is located on the foothill plain at $140 \mathrm{~m}$ above sea level in the forest belt of the Polar Alpine Botanical Garden and Institute (PABGI KSC RAS), whereas the area of the Kirovsk site is situated at an altitude of $340 \mathrm{~m}$ above sea level in the Khibiny Mountains. The duration of the growing season (with an average daily temperatures above $5{ }^{\circ} \mathrm{C}$ ) at the Apatity site is on average 12-15 days longer than at Kirovsk one, and the average long-term sum of active temperatures is $200-250{ }^{\circ} \mathrm{C}$ higher. Other factors indicating more unfavourable conditions on the site of the Khibiny mountains are stony soils that poorly retain moisture and contribute to soil drought, and the site is surrounded by mountain peaks, which limits the flow of solar radiation (a smaller amount of photic active radiation) (Marshall et al., 2016). Thus, the climatic conditions of the protected area PABGI KSC RAS, Kirovsk, are more extreme.

Botanical characteristics of the P. weyrichii. The genus Polygonum, first described by Linnaeus, is the largest genus of the buckwheat family (Polygonaceae) and includes 200 species. The species $P$. weyrichii was first found in the middle part of Sakhalin Island by a participant of the expedition of Admiral Putyatin, a doctor by the name of Weyrich in 1854, in whose honor the name was given. The boundaries of the range over the past 35-40 years have expanded significantly. It has been successfully introduced in the Leningrad, Moscow, Murmansk, Novgorod regions, in the Republic of Belarus, the Baltic states, Western Siberia, and in some areas it is used as a fodder plant (Zhurina \& Kostko, 1996; Zaynullina, 2008).

Weyrich's knotweed ( $P$. weyrichii) is grassy, polymorphic, polycarpic, early vegetative, fast-growing, winter-hardy perennial (Fig. 2).

The root system of Weyrich's knotweed is of mixed type. It consists of a powerfully developed main root with lateral roots located on it and adventitious roots which develop especially intensively beginning from the second year of life. In the first year, adventitious roots are formed on the hypocotyls, which submerges into the soil, and in the following years - on the underground part of annual shoots. The weight of the roots in adult plants reaches $1.5-3.0 \mathrm{~kg}$.

The main root of the Weyrich's knotweed grows in length to $2 \mathrm{~m}$ and more. Starting from the third-fourth year of life, from 1-2 axillary 
buds of the underground part of shoots, 1-2 rhizomes develop, on which shoots and additional roots form (Wu et al., 2004). With age, the diameter of the roots increases. Rhizomes allow the plant to occupy an increasingly large area of nutrition and save it from death during the destruction and gradual death of the central part of the root (Fig. 3).

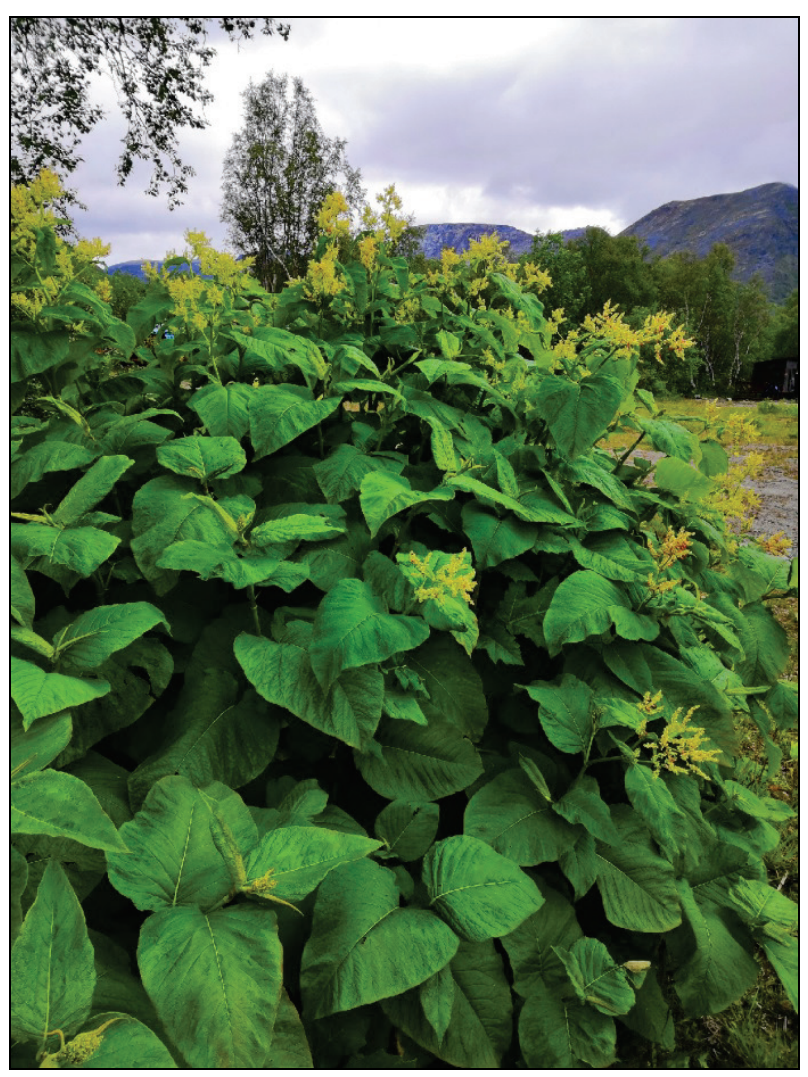

Fig. 2. $P$. weyrichii

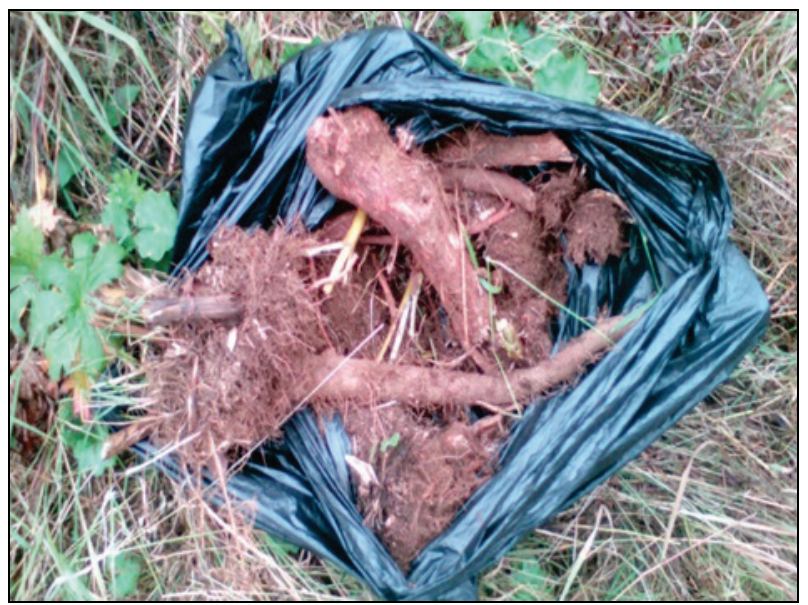

Fig. 3. Underground organs of $P$. weyrichii

The stems of plants are straight, slightly curved at the nodes, deeply furrowed, hollow, pubescent at internodes (weakly below, strongly above), slightly branched. The diameter of the shoots in the lower part is up to $2 \mathrm{~cm}$. At the young age, the stems are green; by the seed ripening phase they turn brown (Fig. 4, 5). Shoots slightly lignify only at the very lower part. The height of the shoots in the first year is up to $1 \mathrm{~m}$, in the second up to $1.5 \mathrm{~m}$, in the third and subsequent years - up to $3.0 \mathrm{~m}$ and more (Zhurina \& Kostko, 1992). The number of stems on a plant also depends on age, in the first year -1 , in the third $-3-4$, in the third $-4-5$, in subsequent years - up to 10 . In the nodes of the stalk there are ochreas up to $5 \mathrm{~cm}$ in size. They serve as a means of protecting inflorescences and growth points against adverse conditions. Leaves are positioned on the ochreas (Fig. 6). The leaves are oval or broadly ovate, slightly cordate, sharp-tipped, with a petiole up to $10 \mathrm{~cm}$ and a leaf blade reaching $30 \mathrm{~cm}$ in length and $15 \mathrm{~cm}$ in width. They are bare above, and covered with thick felt pubescence below (Fig. 7, 8).

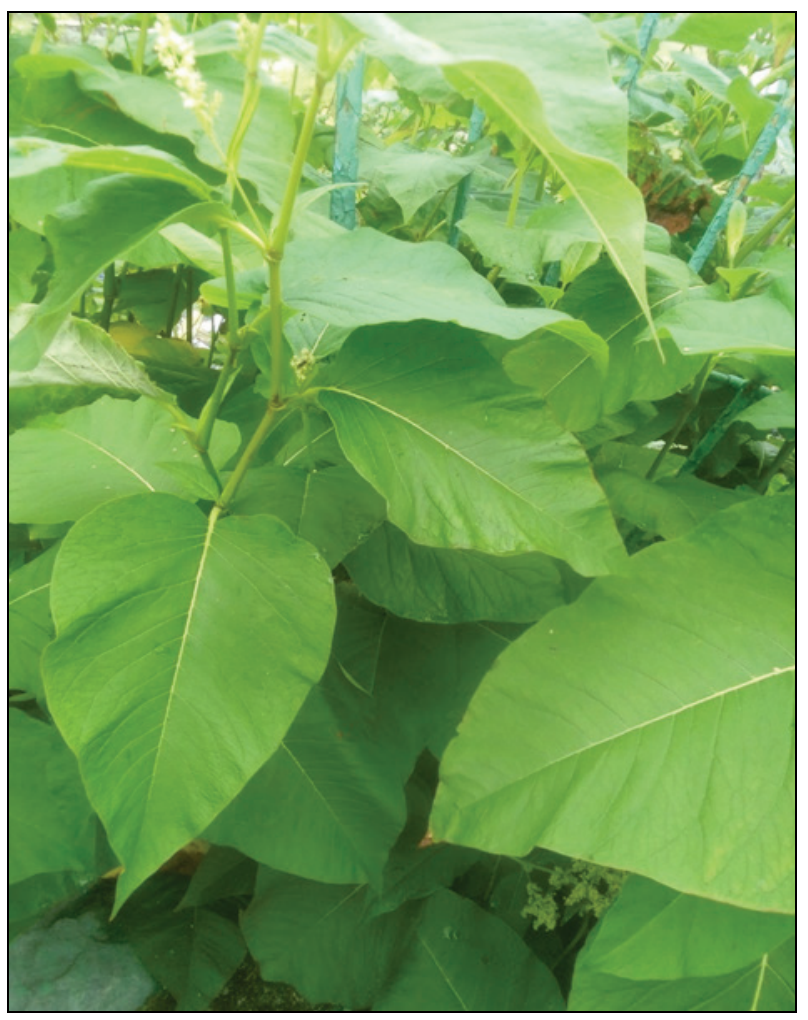

Fig. 4. Stems of young plants of $P$. weyrichii

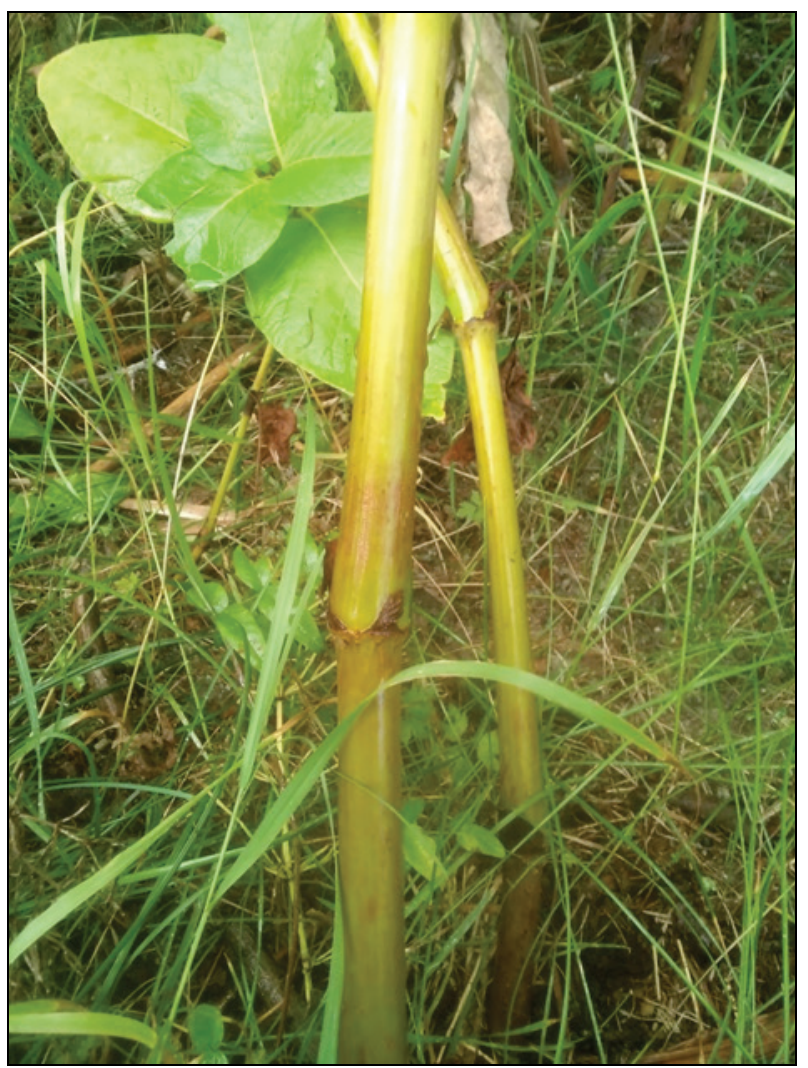

Fig. 5. Stems in the seed ripening phase of $P$. weyrichii

Weyrich's knotweed forms a large number of leaves on one plant. The leafiness of Weyrich's knotweed, depending on the development phase and planting density, changes, with high density, the lower leaves fall off. The inflorescences of Weyrich's knotweed are a loose panicles, terminal and axillary panicles, terminating the main and lateral shoots. 
On the axes, flowers are grouped in 3 to 6 . The inflorescence contains up to 8-9 thousand flowers. The corolla is whitish pink, nondescript, small in size. The flowers of Weyrich's knotweed are morphologically bisexual, but functionally dioecious. There are three types of flowers: 1) short-stamen, or pistillate (functionally female); 2) long stamen, or stamen (functionally male) and 3) transitional type, or bisexual. Pollen flowers do not form pollen, whereas in pistillate flowers, and on the stamen flowers, on the contrary, the germinal sac is not developed (Zhurina \& Kostko, 1992). Bisexual flowers also develop with a bias towards female or male flowers, therefore they bear fruit worse than pistillate ones. The first two types of flowers make up about $85 \%$, and bisexual $15 \%$. They are located on different individuals, so Weyrich's knotweed is considered a dioecious plant. Weather conditions during flowering have a great influence on seed set. Weyrich's knotweed is mainly crosspollinated due to wind and insects (Fig. 9).

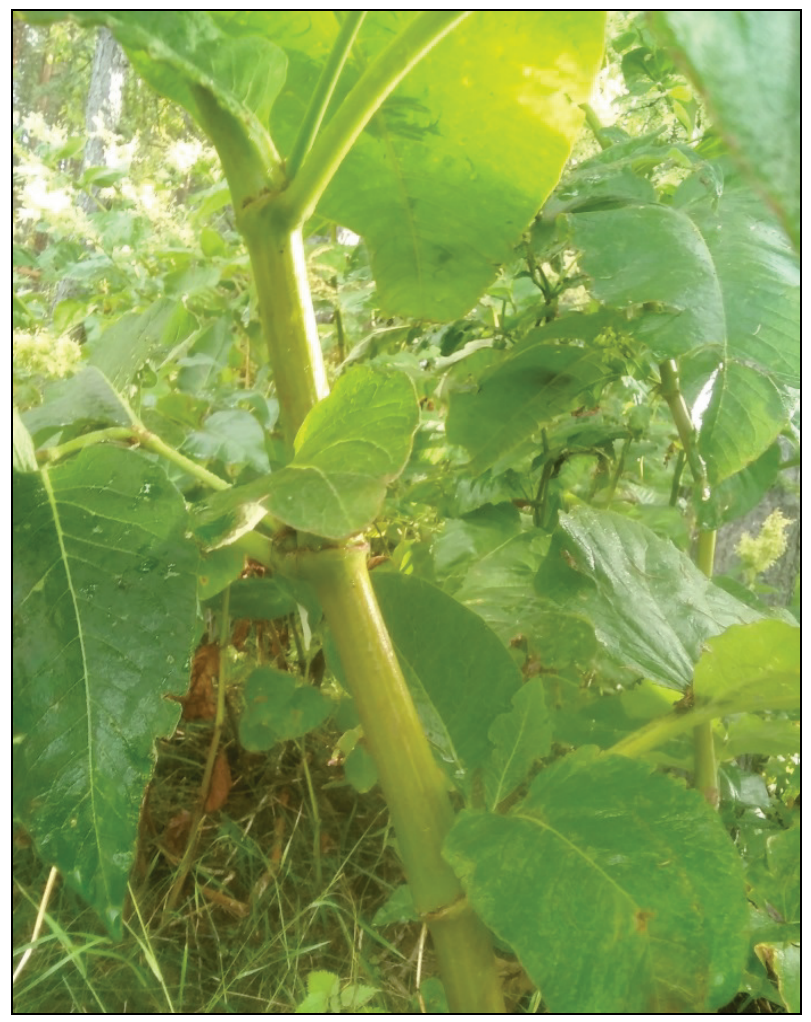

Fig. 6. Bells plants $P$. weyrichii

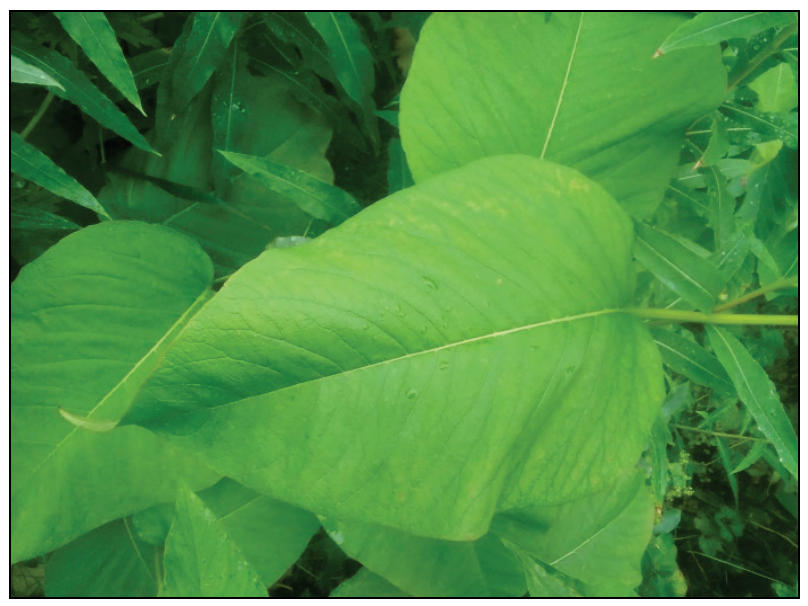

Fig. 7. Top side of leaves of $P$. weyrichii

The fruits are small, they are located in the sepals of three outer perianth lobes. The fruit is a brownish trihedral nut with a mat uneven surface, its length is about $1 \mathrm{~mm}$. Weight of 1,000 fruits (seed) ca 2.5$4.0 \mathrm{~g}$. The Weyrich's knotweed reproduction rate, due to the low seeding rate and fairly good seed productivity (even at low fertility), is rela556 tively high, ranging $40-50$ to $150-200$ or more (Zhurina \& Kostko, 1992). Seeds ripen almost everywhere.

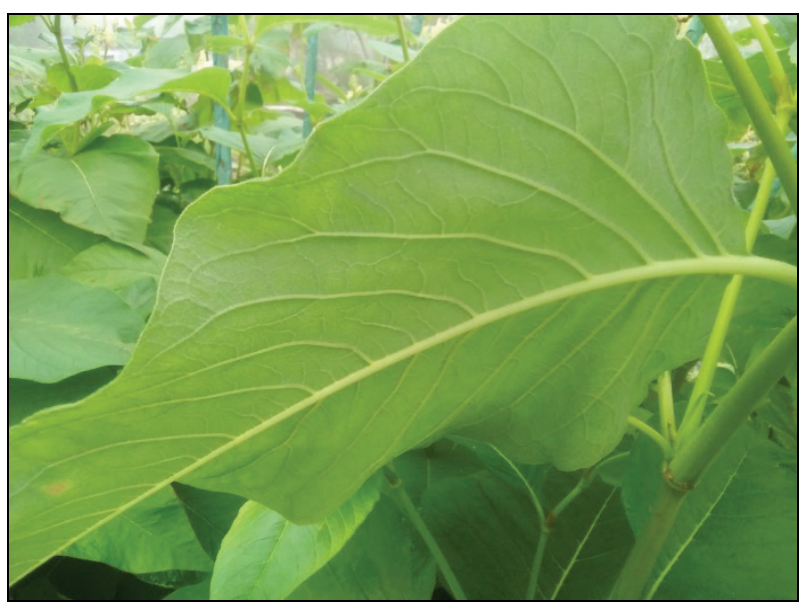

Fig. 8. Bottom side of leaves of $P$. weyrichii

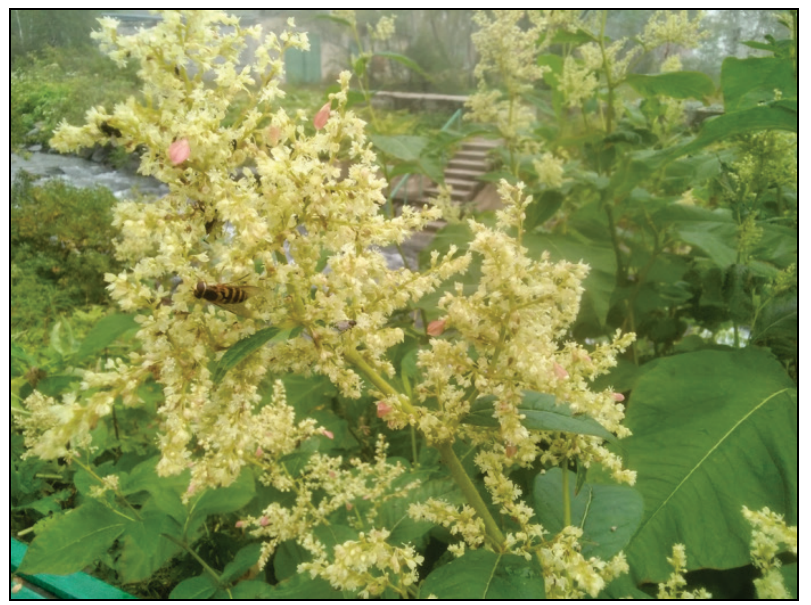

Fig. 9. Inflorescences of $P$. weyrichii

Chemicals. Ethanol 96\% was supplied by Dia M (Moscow, Russia). Methanol (gradient grade for liquid chromatography), sodium carbonate $(>99 \%)$, gallic acid anhydride $(>99 \%)$, sodium nitrite, and aluminum chloride hexahydrate was supplied by Merck (Sofia, Bulgaria). Folin-Ciocalteau reagent, rutin hydrate, quercetin hydrate $(\geq 95 \%)$, tannic acid $(\geq 91 \%)$, pyrogallic acid $(\geq 98 \%),(+)$-catechin hydrate $(\geq 96 \%)$, sodium hydroxide, and Trolox (6-hydroxy-2,5,7,8-tetramethylchroman-2-carboxylic acid) (97\%) were supplied by Sigma Aldrich (St Loius, USA). Ammonia iron alum was supplied by Biochemmak (Moscow, Russia). Deionized water was from a MilliQ water deionizer supplied by Millipore (USA).

Plant material. The material of the upper and middle layers of shoots, inflorescences and underground organs of the $P$. weyrichii plants were grown in protected areas and arboreta of PABGI KSC RAS located in two sites - Kirovsk and Apatity in Murmansk region. We used both wild-growing (in both territories) as well as cultivated (Apatity area only) plants. Plant material was collected on June 10-13 (before flowering), July 10-13 (mass flowering period) and August 25-28 (fruiting period), 2018. The temperatures measured on the days of collection of P. weyrichii were $7.2^{\circ} \mathrm{C}$ in June, $18.7^{\circ} \mathrm{C}$ in July, and $11.0^{\circ} \mathrm{C}$ in August. To ensure representative sampling, $2 \mathrm{~kg}$ of different plant organs were collected. The $P$. weyrichii specimens were identified by experienced biologists from the PABGI KSC RAS.

Extraction procedure. The experiments used the following mixtures of $P$. weyrichii: underground organs, inflorescences, leaves collected in different summer months. After drying and storing, according to the standards established for medicinal raw materials (Waterhouse, 2001), it was grinded in a household coffee grinder and sieved through a $1 \mathrm{~mm}$ sieve. Then, the sifted material was dried for 3 hours at the temperature 
of $+70{ }^{\circ} \mathrm{C}$ (until its weight stabilized). All the samples were used with a LOD (loss on drying) of not more than $10 \%$. For the experiments, a fraction of $0.5-1.0 \mathrm{~mm}$ particle size was used. The initial solid-to-solvent ratio was fixed at 1:20 ( $2 \mathrm{~g}$ of $P$. weyrichii in $40 \mathrm{~mL}$ of solvent). The temperature used for the extraction was room temperature and was kept constant as far as possible. Extractions were performed through magnetic stirring at $1411 \mathrm{RCF}$ (relative centrifugal force) with a magnetic stirrer (MS-H-Pro+, Dragon Laboratory Instruments, Beijing, China). The influence of the solvent composition water or water-ethanol solution $(10,20,30,40,50 \mathrm{v} / \mathrm{v})$ were studied at the 80th min extraction time. Each processed plant material was carefully pressed, and the extract was filtered through cotton and filter paper, and then measured and analyzed immediately after the appropriate dilution (Azwanida, 2015).

Total polyphenol assay according to the Folin-Ciocalteau method (Waterhouse, 2001). A volume of $0.1 \mathrm{~mL}$ of Folin-Ciocalteau reagent was added to a tube, containing $0.02 \mathrm{~mL}$ of the extract (previously diluted to $150 \mathrm{~mL} / \mathrm{L}$ ) and $1.58 \mathrm{~mL}$ of deionized water. A minute later, $0.3 \mathrm{~mL}$ of $20 \% \mathrm{Na}_{2} \mathrm{CO}_{3}$ solution was added to the tube. The samples were kept in a dark place for $2 \mathrm{~h}$ and then the absorbance was measured at $765 \mathrm{~nm}$ against the reagent blank with a UV-vis spectrophotometer (T60UV/VIS, Oasis Scientific Ltd, South Carolina, USA) using a $10 \mathrm{~mm}$ path length cuvette (Waterhouse, 2001). The results were calculated as gallic acid equivalents $\left(\mathrm{y}=0.9119 \mathrm{x}, \mathrm{R}^{2}=0.9892\right)$, pyrogallic acid equivalents $\left(y=1.2114 x, R^{2}=0.9907\right)$ and tannic acid equivalents $\left(y=0.4601 x, R^{2}=0.9120\right)$. The standard calibration curves were obtained with the following standard solution concentration diapasons: a gallic acid solution $(0.1-1.0 \mathrm{mg} / \mathrm{mL})$, a pyrogallic acid solution $(0.1-$ $0.75 \mathrm{mg} / \mathrm{mL})$, and a tannic acid solution $(0.5-2.0 \mathrm{mg} / \mathrm{mL})$.

The total phenolic contents of the $P$. weyrichii extracts was expressed as mg of gallic acid, pyrogallic acid, and tannic acid equivalent per gram dry weight sample (mg GAE, PGAE, TAE/g dw) and calculated by the following formula: $\mathrm{TPC}=\mathrm{C} \times \mathrm{V} \times \mathrm{F} / \mathrm{M}$.
Flavonoid assay. The total flavonoid content (TFC) of the plant extracts was expressed as quercetin, rutin, and $(+)$-catechin equivalents and measured by the aluminum chloride colorimetric assay (Patelet al., 2010). An aliquot of $1 \mathrm{~mL}$ extract (previously diluted to $150 \mathrm{~mL} / \mathrm{L}$ ) was mixed with $4 \mathrm{~mL}$ of deionized water and $0.30 \mathrm{~mL}$ of a $\mathrm{NaNO}_{2}$ solution $(10 \%, \mathrm{w} / \mathrm{v})$. At the 6 th $\mathrm{min}, 0.30 \mathrm{~mL}$ of an $\mathrm{AlCl}_{3}$ solution $(10 \%$, w/v) was added, followed by $2.0 \mathrm{~mL}$ of $\mathrm{NaOH}$ solution $(1 \mathrm{M})$. Immediately after thorough mixing, the absorbance was measured at $510 \mathrm{~nm}$ versus the blank sample. The calibration curves of the used standards were obtained with quercetin $\left(100-1000 \mathrm{mg} / \mathrm{L} ; \mathrm{y}=0.000552 \mathrm{x} ; \mathrm{R}^{2}=0.9977\right)$, rutin $\left(20-100 \mathrm{mg} / \mathrm{L} ; \mathrm{y}=0.00115 \mathrm{x} ; \mathrm{R}^{2}=0.9958\right)$ and $(+)$-catechin $(10$ $\left.200 \mathrm{mg} / \mathrm{L} ; \mathrm{y}=0.00345 \mathrm{x} ; \mathrm{R}^{2}=0.9968\right)$. The results are expressed as quercetin, rutin and (+)-catechin equivalents per gram of dry weight (mg QE, RE, CE/g dw) and calculated by the following formula: TFC $=$ $\mathrm{C} \times \mathrm{Ve} \times \mathrm{F} / \mathrm{M}$, where TFC is the total flavonoid content (mg QE/g dw, $\mathrm{mg} \mathrm{RE} / \mathrm{g} \mathrm{dw}, \mathrm{mg} \mathrm{CE} / \mathrm{g} \mathrm{dw}$ ), $\mathrm{C}$ is the concentration of the used standard $(\mathrm{mg} / \mathrm{L}), \mathrm{Ve}$ is the volume of the used solvent $(\mathrm{L}), \mathrm{F}$ is the dilution coefficient of the sample and $\mathrm{M}$ is the mass of the sample (g).

The total dry residue (TDR) was found gravimetrically after the evaporation of $10 \mathrm{~mL}$ of the extract and through drying of the exhausted preparation to a constant weight in the oven at $105^{\circ} \mathrm{C}$.

All analyses were performed in three replications. The data were analyzed in Statistica 6.0 (StatSoft Inc., USA). The data in the table are presented as $\mathrm{x} \pm \mathrm{SD}$ (mean \pm standard deviation).

\section{Results}

The data obtained indicate the fact that due to the growing place of cultivated and wild plants, the amount of flavonoids in the leaves of the upper and middle layers and in the inflorescences of the plant $P$. weyrichii differs significantly, with the exception of the underground organs in the fruiting period (Table 1).

\section{Table 1}

The flavonoids amount ( $\%$ of dry mass) in the leaves of the upper and middle layers, in the inflorescences and underground organs of Poligonum weyrichii, wild and cultivated plants sampled during the growing season in the Polar Alpine Botanical Garden-Institute (PABSI) area, the Kirovsk and Apatity areas ( $\pm \mathrm{SD}, \mathrm{n}=3$ )

\begin{tabular}{|c|c|c|c|c|c|}
\hline Sampling time & Sampling place & Leaves upper layers & Leaves middle layers & Underground organs & Inflorescences \\
\hline \multirow{3}{*}{$\begin{array}{l}\text { June, 10-13 } \\
\text { (before flowering) }\end{array}$} & cultivated (Apatity) & $2.96 \pm 0.04$ & $3.06 \pm 0.06$ & $0.15 \pm 0.05$ & - \\
\hline & wild (Apatity) & $2.91 \pm 0.03$ & $2.72 \pm 0.06$ & $0.12 \pm 0.03$ & - \\
\hline & wild (Kirovsk) & $3.20 \pm 0.03$ & $3.44 \pm 0.04$ & $0.10 \pm 0.02$ & - \\
\hline \multirow{3}{*}{$\begin{array}{c}\text { July, 10-13 } \\
\text { (massfloweringperiod) }\end{array}$} & cultivated (Apatity) & $2.76 \pm 0.04$ & $2.76 \pm 0.06$ & $0.10 \pm 0.04$ & $2.18 \pm 0.05$ \\
\hline & wild (Apatity) & $2.80 \pm 0.03$ & $2.69 \pm 0.05$ & $0.18 \pm 0.03$ & $2.94 \pm 0.04$ \\
\hline & wild (Kirovsk) & $2.87 \pm 0.03$ & $2.99 \pm 0.02$ & $0.12 \pm 0.03$ & $5.64 \pm 0.03$ \\
\hline \multirow{3}{*}{$\begin{array}{l}\text { August, 25-28 } \\
\text { (fruiting period) }\end{array}$} & cultivated (Apatity) & $2.71 \pm 0.05$ & $2.74 \pm 0.05$ & $0.16 \pm 0.06$ & $3.72 \pm 0.04$ \\
\hline & wild (Apatity) & $2.52 \pm 0.06$ & $2.66 \pm 0.06$ & $0.16 \pm 0.05$ & $3.92 \pm 0.04$ \\
\hline & wild (Kirovsk) & $1.77 \pm 0.04$ & $1.76 \pm 0.04$ & $0.17 \pm 0.03$ & $3.30 \pm 0.04$ \\
\hline
\end{tabular}

Note: "-"- absence of inflorescences.

The flavonoids amount in the above-ground organs was much higher compared to that of the underground organs. The maximum amount of flavonoids $(5.6 \%)$ was found in the inflorescences of the wild plant $P$. weyrichii, found in the PABSI nature reserve area, near Kirovsk, in the period of mass flowering. A great amount of flavonoids was found in the leaves of upper and middle layers of plants growing in the Kirovsk area in the period before flowering and in the period of mass flowering.

The comparison of the amount of flavonoids in the inflorescences of wild and cultivated plants growing in the PABSI area, Apatity, revealed that the flavonoid amount in wild plants was much higher in both periods. The flavonoids amount in inflorescences of wild and cultivated plants increased from the mid-July to the late August, with this increase being more pronounced in cultivated rather than wild plants but the basic flavonoids amount was much higher in wild plants. The seasonal variation of the amount of flavonoids in the inflorescences of plants growing in the Kirovsk area, turned out to be the exact opposite - the flavonoids amount decreased from the period of mass flowering to the period of fruiting.

The general characteristics of the seasonal dynamic of the amount of flavonoids in leaves of both layers were that this amount decreased more or less notably by the end of the summer. As for the plants growing in the Kirovsk area, this amount decreased more significantly.

\section{Discussion}

We found that the flavonoids content in leaves and inflorescences of Weyrich's knotweed growing in territories of the industrially developed central part of Murmansk Oblast can exceed 5.6\% of weight of the dried tissue, although the fruits of Japanese pagoda tree (Styphnolobium japonicum L.), which are now the main source of these compounds, contain up to $16.0 \%$ of flavonoids. Taking into account the higher biomass of Weyrich's knotweed plants, as well resistance to extreme conditions, they can be considered as a promising pharmacologically valuable plant in the Murmansk region. Pilot outcomes will determine the feasibility and possibilities of agricultural technology for further cultivation, the timing and location of collecting samples of wild samples.

According to the generally accepted concepts (Salvamani et al., 2014; del Rio, 2015), activation of the synthesis of scavenger free-radical oxidation adaptogenic complexes in adverse conditions is a common adaptive response of plants. Despite the half-century history of numerous studies on the topic, the issue is not characterized completely. Quite frequent cases of the absence of obvious positive relationships between plant's resistance to the action of extreme environmental factors and compounds exhibiting anti-radical and antioxidant properties can be 
explained by the fact that the background level needed for vitality of free radical oxidation cells, which modulates by its local variations caused by external stimuli, changes, usually increasing with age.

Differences in the content of flavonoids that we identified when comparing cultivated and wild plants (including those living in different territories), as well as their vegetative, generative and wintering organs at different stages of the growing season, can be interpreted from the point of view of modulating the age-related changes in the content of flavonoid complex caused by external influences (Pallavi et al., 2012; Yang et al., 2018). The Kirovsk Territory, located about $200 \mathrm{~m}$ above the Apatity area, is distinguished by a more severe and less continental climate, shorter vegetation season and more pronounced wind load. As for the Apatity area, the conditions of the existence of wild plants are generally worse than those for cultivated plants (Zhirov et al., 2007).

Because accumulation of biologically active substances, including flavonoids, is an age-dependent feature (Jaakola \& Hohtola, 2010) and, as was shown before, the effect of unfavourable factors influences the inclination angle of the ascending and descending branches of the curve of age changes proposed by Krenke (1940), increase in the seasonal differences in content of flavonoids in the leaves of the upper layer in a number of samples: cultivated (Apatity) - wild (Apatity) - wild (Kirovsk) confirms this hypothesis. Increase in the intraseasonal differences in the studied characteristic in this series can be explained by the enhanced development of plants in such conditions. Data on the age basics of the ecological variability of synthesis of flavonoids of the plants of Weyrich's knotweed can be used for developing ecologically safe technology of preparing the raw material base for the regional production of flavonoid preparations.

\section{Conclusions}

Inflorescences and leaves of $P$. weyrichii are the most promising sources of flavonoids in Murmansk region. Ecological peculiarities of flavonoids accumulation in these tissues are associated with changes in the age state of plant organs and show a dependency, postulated in the theory of cyclic aging and plant rejuvenation. Naturalized Weyrich plants in the Murmansk region can be used to create local production of flavonoid preparations necessary for the prevention and treatment of cardiovascular diseases that are widespread in the Arctic regions. The results of this study can be used as the theoretical basis of technologies for the production of adaptogenic drugs in the North.

Acknowledgement: The authors are grateful to the head of the Laboratory of Biomedical Technologies of the Kola Science Center (Russian Academy of Sciences), PhD Dina Petrashova, Senior researcher of the Biological Institute of the Karelian Science Center (Russian Academy of Sciences) PhD Sergey Kolomeichuk and junior researcher at the Research Centre for Human Adaptation in the Arctic - Branch of the Federal Research Centre "Kola Science Centre of the Russian Academy of Science " Roman Mihajlov for administrative and technical support of the research.

\section{References}

Azwanida, N. N. (2015). A review on the extraction methods use in medicinal plants, principle, strength and limitation. Medicinal and Aromatic Plants, 4, 196.

Brunetti, C., Di Ferdinando, M., Fini, A., Pollastri, S., \& Tattini, M. (2013). Flavonoids as antioxidants and developmental regulators: Relative significance in plants and humans. International Journal of Molecular Sciences, 14(2), 3540-3555.

Carocho, M., \& Ferreira, I. C. F. R. (2013). A review on antioxidants, prooxidants and related controversy: Natural and synthetic compounds, screening and analysis methodologies and future perspectives. Food and Chemical Toxicology, 51, $15-25$.

Cheynier, V., Comte, G., Davies, K. M., Lattanzio, V., \& Martens, S. (2013). Plant phenolics: Recent advances on their biosynthesis, genetics, and ecophysiology. Plant Physiology and Biochemistry, 72, 1-20.

del Rio, L. A. (2015). ROS and RNS in plant physiology: an overview. Journal of Experimental Botany, 66(10), 2827-2837.

Eghbaliferiz, S., \& Iranshahi, M. (2016). Prooxidant activity of polyphenols, flavonoids, anthocyanins and carotenoids: Updated review of mechanisms and catalyzing metals. Phytotherapy Research, 30(9), 1379-1391.
Guo, H., Wan, X. H., Niu, F. J., Sun, J. J., Shi, C. X., Ye, J. M., \& Zhou, C. Z. (2019). Evaluation of antiviral effect and toxicity of total flavonoids extracted from Robinia pseudoacacia cv. idaho. Biomedicine and Pharmacotherapy, 118,109335

Hasnulin, V. I. (2007). Geophysical pertubations as the main cause of northern human stress. Alaska Medicine, 49(2), 237-244.

Incalza, M. A., D’Oria, R., Natalicchio, A., Perrini, S., Laviola, L., \& Giorgino, F. (2018). Oxidative stress and reactive oxygen species in endothelial dysfunction associated with cardiovascular and metabolic diseases. Vascular Pharmacology, 100, 1-19.

Jaakola, L., \& Hohtola, A. (2010). Effect of latitude on flavonoid biosynthesis in plants. Plant Cell and Environment, 33(8), 1239-1247.

Kim, Y., \& Je, Y. (2017). Flavonoid intake and mortality from cardiovascular disease and all causes: A meta-analysis of prospective cohort studies. Clinical Nutrition Espen, 20, 68-77.

Korovkina, A. V. (2019). Perspektiva primenenija rastitel'nyh flavonoidov dlja profilaktiki serdechno-sosudistyh zabolevanij v uslovijah Kol'skogo Zapoljar'ja [The prospect of using plant flavonoids for the prevention of cardiovascular diseases in the Kola Arctic]. Colloquium, 34, 38 -40 (in Russian).

Krenke, N. P. (1940). Teorija ciklicheskogo starenija i omolozhenija rastenij i ee prakticheskoe primenenie [Theory of cyclic aging and rejuvenation plants and its practical application]. Book-on-Demand, Moscow (in Russian).

Law, K. S., Roiger, A., Thomas, J. L., Marelle, L., Raut, J. C., Dalsoren, S., \& Schlager, H. (2017). Local arctic air pollution: Sources and impacts. Ambio, 46, 453-463.

Maleki, S. J., Crespo, J. F., \& Cabanillas, B. (2019). Anti-inflammatory effects of flavonoids. Food Chemistry, 2019, 299.

Marshall, G. J., Vignols, R. M., \& Rees, W. G. (2016). Climate change in the Kola Peninsula, Arctic Russia, during the last 50 years from meteorological observations. Journal of Climate, 29(18), 6823-6840.

Nimse, S. B., \& Pal, D. (2015). Free radicals, natural antioxidants, and their reaction mechanisms. Royal Society of Chemistry Advances, 5(35), 27986-28006.

Pallavi, S., Ambuj, B. J., Rama, S. D., \& Mohammad, P. (2012). Reactive oxygen species, oxidative damage, and antioxidative defense mechanism inplants under stressful conditions. Journal of Botany, 2012, 217037.

Panche, A. N., Diwan, A. D., \& Chandra, S. R. (2016). Flavonoids: An overview. Journal of Nutritional Science, 5, e47.

Patel, A., Patel, A., \& Patel, N. M. (2010). Determination of polyphenols and free radical scavenging activity of Tephrosia purpurea Linn leaves (Leguminosae). Pharmacognosy Research, 2(3), 152-158.

Phaniendra, A., Jestadi, D. B., \& Periyasamy, L. (2015). Free radicals: Properties, sources, targets, and their implication in various diseases. Indian Journal of Clinical Biochemistry, 30(1), 11-26.

Salvamani, S., Gunasekaran, B., Shaharuddin, N. A., Ahmad, S. A., \& Shukor, M. Y. (2014). Antiartherosclerotic effects of plant flavonoids. Biomed Research International, 2014, 480258.

Shreter, A. I., Trofimova, I. A., Rudenskaja, R. N., \& Golovkin, B. N. (2002). Biologicheski aktivnye veshhestva rastitel'nogo proishozhdenija [Biologically active substances of plant origin]. Nauka, Moscow (in Russian).

Siasos, G., Tousoulis, D., Tsigkou, V., Kokkou, E., Oikonomou, E., Vavuranakis, M., Basdra, E. K., Papavassiliou, A. G., \& Stefanadis, C. (2013). Flavonoids in atherosclerosis: An overview of their mechanisms of action. Current Medicinal Chemistry, 20(21), 2641-2660.

Siddiqi, A., Saidullah, B., \& Sultana, S. (2018). Anti-carcinogenic effect of hesperidin against renal cell carcinoma by targeting COX-2/PGE2 pathway in Wistar rats. Environmental Toxicology, 33(10), 1069-1077.

Suganya, N., Dornadula, S., Chatterjee, S., \& Mohanram, R. K. (2018). Quercetin improves endothelial function in diabetic rats through inhibition of endoplasmic reticulum stress-mediated oxidative stress. European Journal of Pharmacology, 819, 80-88.

Sunil, C., \& Xu, B. J. (2019). An insight into the health-promoting effects of taxifolin (dihydroquercetin). Phytochemistry, 2019, 112066.

Vazhappilly, C. G., Ansari, S. A., Al-Jaleeli, R., Al-Azawi, A. M., Ramadan, W. S., Menon, V., Hodeify, R., Siddiqui, S. S., Merheb, M., Matar, R., \& Radhakrishnan, R. (2019). Role of flavonoids in thrombotic, cardiovascular, and inflammatory diseases. Inflammopharmacology, 27(5), 863-869.

Wang, S. H., Hu, Y. L., \& Liu, T. X. (2019). Plant distribution and pharmacological activity of flavonoids. Traditional Medicine Research, 4(5), 269-287.

Waterhouse, A. L. (2003). Determination of total phenolics. Current Protocols in Food Analytical Chemistry. John Wiley \& Sons, New York.

Wu, B. Y., Isobe, K., \& Ishii, R. (2004). Arbuscular mycorrhizal colonization of the dominant plant species in primary successional volcanic deserts on the Southeast slope of Mount Fuji. Mycorrhiza, 14(6), 391-395.

Yang, L., Wen, K.-S., Ruan, X., Zhao, Y.-X., Wei, F., \& Wang, Q. (2018). Response of plant secondary metabolites to environmental factors. Molecules, 23(4), e23040762.

Zajnullina, K. S. (2008). Introdukcija kormovyh rastenij v respublike Komi [Introduction of fodder plants in the Komi Republic]. Vestnik Instituta Biologii 
Komi Nauchnogo Centra Ural'skogo Otdelenija Rossijskoj Akademii Nauk, 129, 37-39 (in Russian).

Zeng, X. Q., Xi, Y., \& Jiang, W. B. (2019). Protective roles of flavonoids and flavonoid-rich plant extracts against urolithiasis: A review. Critical Reviews in Food Science and Nutrition, 59(13), 2125-2135.

Zhang, H., \& Tsao, R. (2016). Dietary polyphenols, oxidative stress and antioxidant and anti-inflammatory effects. Current Opinion in Food Science, 8, 33- 42.

Zhirov, V. K., Golubeva, E. I., Govorova, A. F., \& Haitbaev, A. H. (2007). Strukturno-funkcional'nye izmenenija rastitel'nosti v uslovijah tehnogennogo zagrjaz- nenija na Krajnem severe [Structural and functional changes of vegetation in the conditions of technogenic pollution in the Far North]. Nauka, Moscow (in Russian).

Zhurina, L. L., \& Kostko, I. G. (1992). Osobennosti biometricheskoj struktury travostoja i fitoklimata posevov Polygonum weirichii [Features of biometric structure of grass stand and phytoclimate of Polygonum weirichii]. Priemy poluchenija vysokih urozhaev polevyh kul'tur na severo-zapade Nechemozemnoj zony, 64-67 (in Russian). 